\title{
Pemetaan Tingkat Kekeringan Berdasarkan Parameter Indeks TVDI Data Citra Satelit Landsat-8 (Studi Kasus: Provinsi Jawa Timur)
}

\author{
Diah Witarsih dan Bangun Muljo Sukojo \\ Jurusan Teknik Geomatika, Fakultas Teknik Sipil dan Perencanaan, Institut Teknologi Sepuluh \\ Nopember (ITS) \\ Jl. Arief Rahman Hakim, Surabaya 60111 Indonesia \\ email: bangunms@gmail.com
}

\begin{abstract}
Abstrak - Kekeringan merupakan salah satu bencana yang sering terjadi di berbagai daerah di Indonesia. Kekeringan erat hubungannya dengan ketidakseimbangan antara kebutuhan dan pasokan air. Kekeringan datang secara berulang tiap tahunnya dan sulit dicegah. Kekeringan terjadi dengan intensitas dan luas yang berbeda-beda tiap tahunnya. Peningkatan intensitas dan luas bencana kekeringan berpengaruh besar terhadap berbagai sektor. Menurut Badan Penanggulangan Bencana Daerah (2015), beberapa wilayah di Provinsi Jawa Timur mengalami tingkat kekeringan yang sangat tinggi dan luasnya wilayah terdampak. Oleh karena itu, perlu adanya pemantauan dan prediksi tingkat kekeringan di wilayah Provinsi Jawa Timur dengan monitoring secara berkala dalam kurun waktu tertentu serta diperlukan data yang dapat digunakan secara efisien dalam monitoring tersebut. Salah satu data citra satelit yang dapat digunakan dalam monitoring kekeringan adalah citra Satelit Landsat-8. Pemantauan kekeringan dilakukan pada wilayah Provinsi Jawa Timur dalam kurun waktu 3 tahun (2013-2015) berdasarkan parameter Temperature Vegetation Dryness Index. Perhitungan parameter indeks TVDI ini didasarkan pada hubungan linier antara nilai indeks vegetasi dengan suhu permukaan tanah dan dalam perhitungan nilai suhu permukaan tanahnya menggunakan metode Split Window Algorithm. Algoritma ini memperhitungkan nilai emisivitas dari tutupan lahan dan watervapour content dari study area. Nilai emisivitas yang digunakan dalam perhitungan Land Surface Temperature (LST) adalah nilai mean dan different dari nilai Land Surface Emissivity (LSE). Hasil yang diperoleh dari penelitian ini berdasarkan perhitungan nilai TVDI yaitu adanya perbedaan nilai rata-rata kekeringan antara tahun 2013 dengan tahun 2014 yaitu mengalami penurunan sebesar 0,008 . Sedangkan antara tahun 2014 dengan tahun 2015 mengalami peningkatan sebesar 0,015 .
\end{abstract}

Kata Kunci- Kekeringan, Landsat-8, TVDI.

\section{PENDAHULUAN}

$\mathrm{K}$ EKERINGAN merupakan salah satu bencana yang sering terjadi di berbagai daerah di Indonesia. Kekeringan erat hubungannya dengan ketidakseimbangan antara kebutuhan dan pasokan air. Bencana kekeringan datang secara berulang tiap tahunnya. Secara umum definisi kekeringan adalah kondisi ketersediaan air di suatu wilayah yang semakin berkurang dalam periode waktu yang cukup panjang akibat berkurangnya intensitas curah hujan di wilayah tersebut. Kekeringan terjadi dengan intensitas dan luas yang berbedabeda tiap tahunnya [1]

Periode musim kemarau semakin meningkat dan terjadi lebih awal tiap tahunnya akibat pemanasan global yang semakin tinggi serta pengaruh fenomena El-Nino. Gejala-gejala tersebut pada akhirnya berdampak pada semakin panjangnya rentang waktu terjadinya bencana kekeringan, serta semakin luasnya area terdampak [2]. Ditambahkan lagi oleh [3], Peningkatan intensitas dan luas bencana kekeringan berpengaruh besar terhadap berbagai sektor. Dampak kekeringan, selain berkurangnya ketersediaan dan pasokan air, juga terjadi penurunan produksi pangan, dan kebakaran lahan/hutan.

Oleh sebab itu, pemantauan dan prediksi kekeringan menjadi kegiatan yang sangat penting untuk dilakukan, agar dampak kekeringan dapat diminimalkan. Pemantauan dan prediksi kekeringan telah dilakukan dengan berbagai metode. Parameter yang diperoleh dari algoritma yang digunakan harus mampu merepresentasikan tingkat kekeringan dari suatu wilayah dengan baik.

Pada penelitian ini, digunakan data perhitungan tingkat kekeringan berdasarkan parameter indeks TVDI yang diperoleh dari hubungan segitiga antara nilai indeks vegetasi NDVI dengan nilai suhu permukaan dari citra satelit Landsat-8 secara multitemporal untuk wilayah kajian studi Provinsi Jawa Timur. Pemilihan wilayah kajian studi berdasarkan tingginya tingkat kekeringan dan luasnya wilayah terdampak dari laporan Badan Penanggulangan Bencana Daerah (BPBD) Provinsi Jawa Timur.

\section{METODOLOGI PENELITIAN}

\section{A. Lokasi Penelitian}

Lokasi yang dipilih dalam penelitian ini adalah wilayah Provinsi Jawa Timur. Secara geografis terletak pada koordinat antara $7^{0} 12^{\prime}-8^{0} 48^{\prime}$ Lintang Selatan dan $111^{0} 0^{\prime}-114^{0} 4^{\prime}$ Bujur Timur. Luas wilayah sebesar $47.963 \mathrm{~km}^{2}$ yang meliputi wilayah daratan Jawa Timur sebesar $88,7 \%$ atau $42.541 \mathrm{~km}^{2}$ dan Kepulauan Madura dengan luas 11,30\% atau sebesar $5.422 \mathrm{~km}^{2}$ [4]. Batasan wilayah yang digunakan adalah data batas administrasi wilayah Provinsi Jawa Timur. 


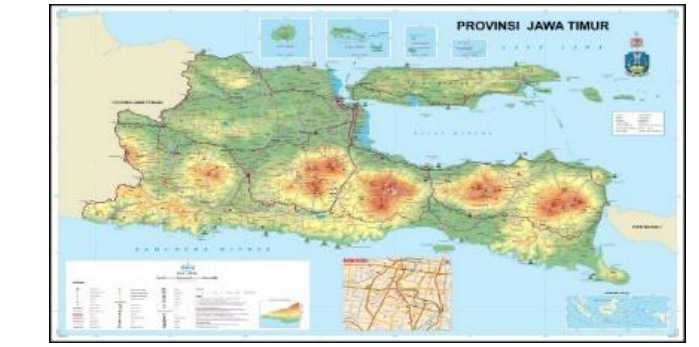

Gambar 1. Lokasi Studi Penelitian Provinsi Jawa Timur [5]

\section{B. Data yang Digunakan}

Penelitian ini menggunakan data antara lain data citra satelit Landsat-8 Path/Row 117-119/65-66 dengan akuisisi data tahun 2013 hingga 2015, data batas administrasi Provinsi Jawa Timur 1:2.180.662 dari digitasi peta RBI 1:25.000, data kelembaban nisbi udara rata-rata tahun 2013-2015, serta data curah hujan rata-rata pada tahun 2013-2015.

\section{Pengolahan Data}

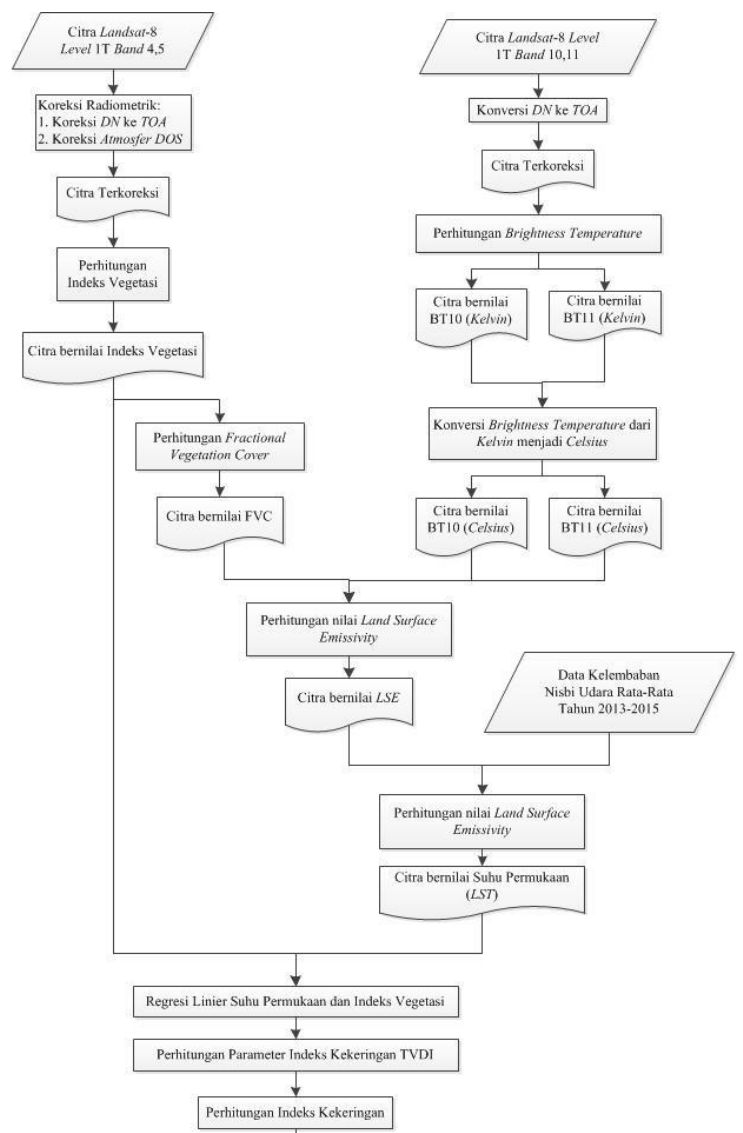

Gambar 2. Diagram Alir Pengolahan Data

Penjelasan dari diagram alir di atas adalah sebagai berikut:

1) Koreksi Citra

Koreksi pada data citra Landsat-8 hanya dilakukan koreksi radiometrik, karena data telah terkoreksi secara geometrik. Produk data citra yang digunakan adalah Landsat-8 OLI/TIRS Level IT, dimana data ini merupakan Terrain Corrected Products (Precision Ortho-Corrected) [6]. Sehingga koreksi yang diperlukan hanyalah koreksi radiometrik.
Pada band multispectral (band 4 dan 5) langkah pertama yang dilakukan adalah mengubah nilai $D N$ dari citra menjadi nilai reflectance, serta koreksi atmosfer Dark Object Substraction (DOS). Sedangkan untuk band Thermal diubah dari nilai $D N$ citra menjadi nilai radiance.

2) Perhitungan Algoritma NDVI

3) Perhitungan Brightness Temperature

a) Perhitungan nilai Fractional Vegetation Cover (FVC)

b) Perhitungan nilai Land Surface Emmissivity (LSE)

c) Perhitungan nilai Land Surface Temperature (LST)

4) Hubungan regresi linier Nilai NDVI dan LST dari hasil scatterplot

5) Perhitungan TVDI

\section{HASIL DAN ANALISA}

\section{A. Hasil Pengolahan Indeks Vegetasi NDVI}

Dalam penelitian ini digunakan 35 titik sample yang tersebar di seluruh Provinsi Jawa Timur untuk memperoleh nilai ekstraksi hasil pengolahan citra. Distribusi spasial titik sample tersebut seperti ditunjukkan pada gambar berikut:

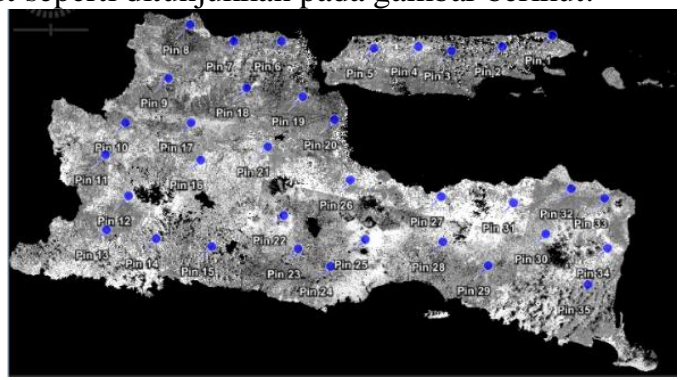

Gambar 1. Distribusi Spasial Titik Sample Penelitian

Titik-titik sample tersebut tidak hanya digunakan untuk perhitungan nilai indeks vegetasi, tetapi juga digunakan untuk perhitungan nilai suhu permukaan tanah dan indeks kekeringan TVDI. Perhitungan nilai indeks vegetasi NDVI yang telah dilakukan menunjukkan perubahan nilai indeks vegetasi di wilayah Provinsi Jawa Timur seperti gambar berikut:

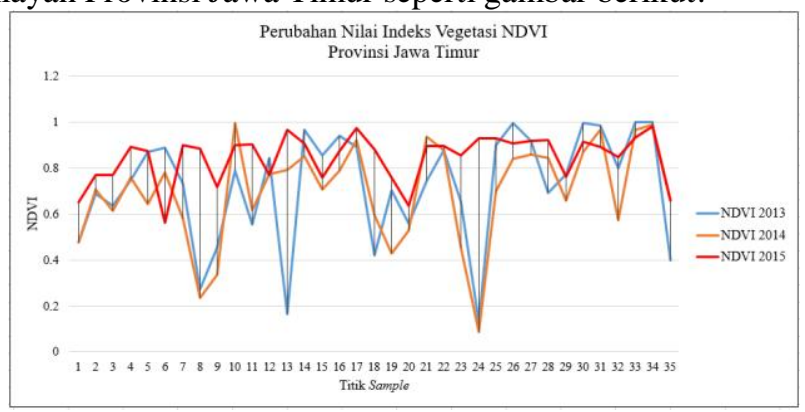

Gambar 2. Perubahan Nilai Indeks Vegetasi NDVI Provinsi Jawa Timur Tahun 2013-2015

Pada tahun 2013, tingkat indeks vegetasi NDVI terendah adalah 0,127 dan nilai indeks vegetasi tertingi adalah 0,999. Pada tahun 2014, tingkat indeks vegetasi NDVI paling rendah adalah 0,088 dan nilai indeks vegetasi tertingi adalah 0,997. Sedangkan pada tahun 2015, tingkat indeks vegetasi NDVI paling rendah adalah 0,561 dan nilai indeks vegetasi tertingi adalah 0,982. Nilai indeks vegetasi rata-rata pada tahun 2013 sebesar 0,724, pada tahun 2014 sebesar 0,698, dan pada tahun 
2015 sebesar 0,846. Antara tahun 2013 hingga 2014 mengalami penurunan sebesar 0,026 , sedangkan dari tahun 2014 hingga 2015 mengalami peningkatan sebesar 0,148 seperti ditunjukkan pada tabel berikut:

Tabel 1.

Hasil Perhitungan Nilai Indeks Vegetasi NDVI

\begin{tabular}{cccc}
\hline \hline Tahun & NDVI Terendah & NDVI Tertinggi & NDVI Rata-Rata \\
\hline 2013 & 0,127 & 0,999 & 0,724 \\
2014 & 0,088 & 0,997 & 0,698 \\
2015 & 0,561 & 0,982 & 0,846 \\
\hline \hline
\end{tabular}

\section{B. Hasil Pengolahan Suhu Permukaan Tanah (LST)}

Perhitungan nilai suhu permukaan tanah yang telah dilakukan menunjukkan bahwa perubahan nilai suhu permukaan tanah di wilayah Provinsi Jawa Timur seperti gambar berikut:

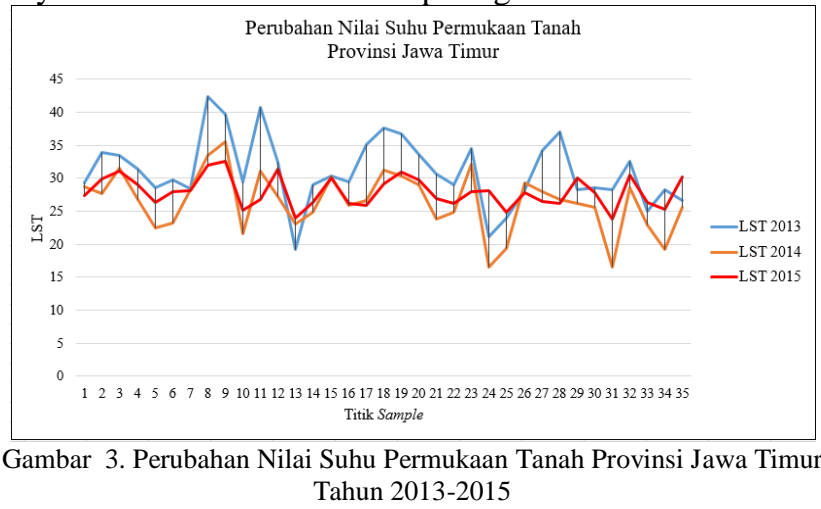

Nilai suhu permukaan tanah Provinsi Jawa Timur pada tahun 2013, paling rendah adalah $19,26^{\circ} \mathrm{C}$ dengan nilai suhu permukaan tertinggi sebesar $42,33^{\circ} \mathrm{C}$. Pada tahun 2014, nilai suhu permukaan terendah sebesar $16,51^{\circ} \mathrm{C}$ dan nilai tertinggi adalah $35,6^{\circ} \mathrm{C}$. Sedangkan pada tahun 2015 , nilai terendah $23,78^{\circ} \mathrm{C}$ dengan nilai tertinggi yaitu $32,58^{\circ} \mathrm{C}$. Nilai suhu permukaan rata-rata pada tahun 2013 sebesar $31,07^{\circ} \mathrm{C}$, pada tahun 2014 sebesar $26,41^{\circ} \mathrm{C}$, dan pada tahun 2015 sebesar $27,96^{\circ} \mathrm{C}$. Pada tahun 2013 hingga 2014 mengalami penurunan sebesar $4,65^{\circ} \mathrm{C}$, sedangkan dari tahun 2014 hingga 2015 mengalami peningkatan sebesar $1,55^{\circ} \mathrm{C}$ seperti ditunjukkan pada tabel berikut:

Tabel 2.

Hasil Perhitungan Suhu Permukaan Tanah (LST)

\begin{tabular}{cccc}
\hline Tahun & $\begin{array}{c}\text { LST Tertinggi } \\
\left({ }^{\circ} \mathbf{C}\right)\end{array}$ & $\begin{array}{c}\text { LST Terendah } \\
\left({ }^{\circ} \mathbf{C}\right)\end{array}$ & $\begin{array}{c}\text { LST Rata-Rata } \\
\left({ }^{\circ} \mathbf{C}\right)\end{array}$ \\
\hline 2013 & 42,33 & 19,26 & 31,07 \\
2014 & 35,6 & 16,51 & 26,41 \\
2015 & 32,58 & 23,78 & 27,96 \\
\hline \hline
\end{tabular}

\section{Hubungan Regresi Linier antara Nilai NDVI dan LST}

Scatterplot antara nilai Suhu Permukaan Tanah (LST) dan nilai Indeks Vegetasi NDVI diperoleh persamaan nilai Indeks Kekeringan TVDI dengan masing-masing nilai koefisien determinasi dari masing-masing perhitungan seperti pada gambar berikut:

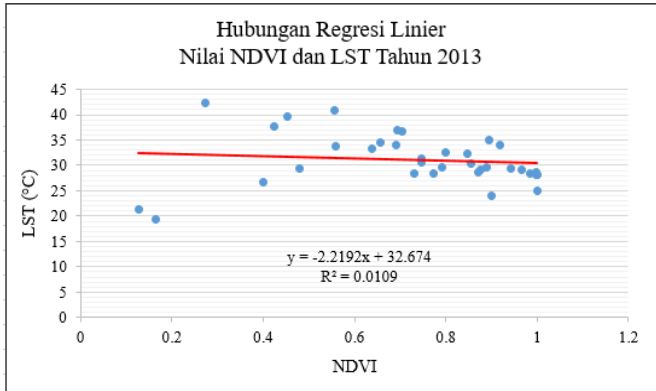

Gambar 4. Scatterplot Nilai LST dan NDVI pada Tahun 2013

Hasil scatterplot diketahui bahwa antara nilai suhu permukaan tanah dengan nilai indeks vegetasi memiliki hubungan negatif, dimana semakin tinggi tingkat kerapatan indeks vegetasi maka nilai suhu permukaan tanahnya akan semakin rendah. Sebaliknya apabila tingkat kerapatan indeks vegetasi di suatu wilayah rendah maka nilai suhu permukaan tanah di wilayah tersebut semakin tinggi. Pada tahun 2013 nilai optimum berada pada nilai indeks vegetasi antara 0,6 hingga 1 dengan nilai suhu permukaan tanah antara $25^{\circ} \mathrm{C}$ hingga $40^{\circ} \mathrm{C}$. Besarnya koefisien determinasi menunjukkan besar pengaruh nilai indeks vegetasi terhadap nilai suhu permukaan tanah pada tahun 2013 yaitu sebesar 0,0109 atau 1,09\%.

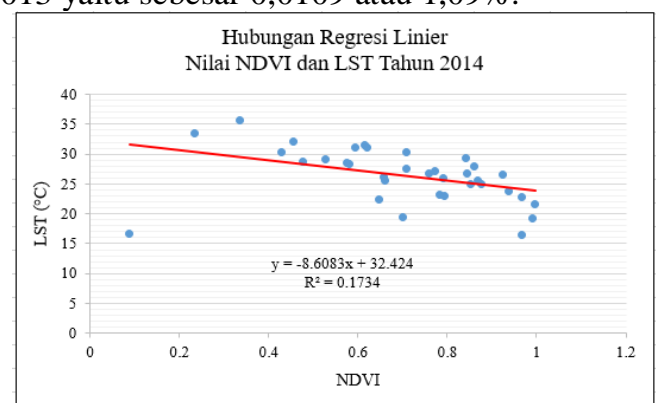

Gambar 5. Scatterplot Nilai LST dan NDVI pada Tahun 2014

Hasil scatterplot pada tahun 2014 menunjukkan bahwa antara nilai suhu permukaan tanah dengan nilai indeks vegetasi memiliki hubungan negatif, dimana nilai optimum pada tahun 2014 berada pada nilai indeks vegetasi antara 0,6 hingga 1 dengan nilai suhu permukaan tanah antara $20^{\circ} \mathrm{C}$ hingga $35^{\circ} \mathrm{C}$. Dimana besar pengaruh nilai indeks vegetasi terhadap suhu permukaan tanah pada tahun 2014 sebesar 0,1734 atau sebesar $17,34 \%$.

Sedangkan hasil scatterplot pada tahun 2015 menunjukkan bahwa antara nilai indeks vegetasi dengan suhu permukaan tanah juga memiliki hubungan negatif. Nilai optimum pada tahun ini berada pada nilai indeks vegetasi 0,8 hingga 1 dengan suhu permukaan tanah berada pada rentang $20^{\circ} \mathrm{C}$ hingga $35^{\circ} \mathrm{C}$. Besarnya pengaruh nilai indeks vegetasi terhadap suhu permukaan tanah pada tahun 2015 sebesar 0,3382 atau 33,82\%.

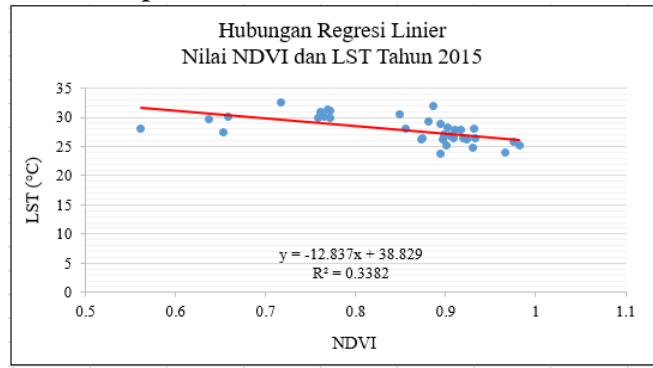


Gambar 6. Scatterplot Nilai LST dan NDVI pada Tahun 2015

\section{Analisa Hubungan Regresi Linier antara Nilai Indeks} Vegetasi NDVI dan Land Surface Temperature

Hubungan Regresi Linier antara indeks vegetasi NDVI dan Land Surface Temperature (Suhu Permukaan Tanah) pada tahun 2013 hingga 2015 seperti pada tabel berikut:

Tabel 3.

Hasil Regresi Linier NDVI dan LST

\begin{tabular}{cccc}
\hline \hline Tahun & $\mathbf{R}$ & $\mathbf{R}^{2}$ & \multicolumn{1}{c}{ Persamaan Linier } \\
\hline 2013 & 0,105 & 0,011 & LST $=32,674-2,219$ NDVI \\
2014 & 0,416 & 0,173 & LST $=32,424-8,608$ NDVI \\
2015 & 0,582 & 0,338 & LST $=38,829-12,837$ NDVI \\
\hline \hline
\end{tabular}

Dari tabel di atas terlihat bahwa korelasi tertinggi antara nilai indeks vegetasi dan suhu permukaan tanah pada tahun 2015 yaitu sebesar 0,582 dan besar koefisien determinasinya sebesar 0,338 atau $33,8 \%$ seperti dijelaskan pada pembahasan hasil scatterplot tahun 2015 di atas. Hubungan regresi linier antara nilai indeks vegetasi pada tahun 2015 ditunjukkan pada gambar 12.

Sedangkan korelasi terendah antara nilai indeks vegetasi dan suhu permukaan tanah yaitu pada tahun 2013 sebesar 0,105 dan besar koefisien determinasinya adalah 0,011 atau $1,1 \%$ seperti dijelaskan pada pembahasan hasil scatterplot pada tahun 2013 di atas. Hubungan regresi linier antara nilai indeks vegetasi dengan suhu permukaan tanah pada tahun 2013 ditunjukkan pada gambar 14

Besar korelasi nilai indeks vegetasi dan suhu permukaan tanah pada tahun 2014 yaitu sebesar 0,416 dengan besar koefisien determinasinya yaitu 0,173 atau $17,3 \%$ seperti yang telah dijelaskan pada pembahasan hasil scatterplot pada tahun $2014 \mathrm{di}$ atas. Hubungan regresi linier antara indeks vegetasi dengan suhu permukaan tanah pada tahun 2014 ditunjukkan pada gambar 13 .

\section{E. Hasil Perhitungan Indeks Kekeringan TVDI}

Perhitungan nilai indeks kekeringan TVDI diperoleh seperti pada tabel berikut:

Tabel 4.

Hasil Perhitungan Indeks Kekeringan TVDI Provinsi Jawa Timur

\begin{tabular}{cccc}
\hline \hline Tahun & TVDI Tertinggi & TVDI Terendah & TVDI Rata-Rata \\
\hline 2013 & 1,068 & 0,934 & 0,993 \\
2014 & 1,052 & 0,921 & 0,986 \\
2015 & 1,03 & 0,967 & 1 \\
\hline \hline
\end{tabular}

Pada tahun 2013 nilai indeks kekeringan tertinggi 1,068 dan terendah 0,934. Tahun 2014 nilai indeks kekeringan tertinggi sebesar 1,052 sedangkan nilai terendah sebesar 0,921. Pada tahun 2015 nilai indeks kekeringan tertinggi yaitu 1,03 dan nilai terendah 0,967 . Nilai indeks kekeringan rata-rata pada tahun 2013 sebesar 0,993, tahun 2014 sebesar 0,986, dan pada tahun 2015 sebesar 1. Pada tahun 2013 hingga 2014 tingkat kekeringan di Provinsi Jawa Timur mengalami penurunan sebesar 0,008 sedangkan tahun 2014 hingga 2015 mengalami peningkatan sebesar 0,015 .Perubahan nilai rata-rata antara tahun 2013 dengan tahun 2014 mengalami penurunan sebesar 0,046 . Sedangkan antara tahun 2014 dengan tahun 2015 mengalami peningkatan sebesar 0,05. Hasil plotting perhitungan nilai indeks kekeringan ditunjukkan seperti gambar berikut:

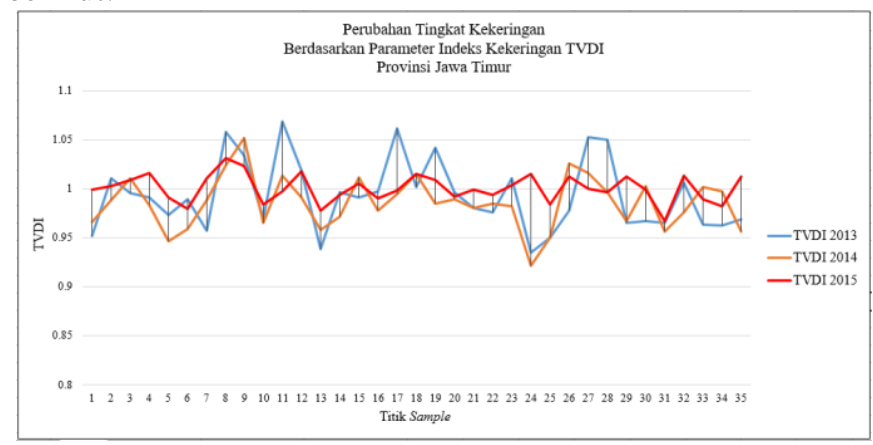

Gambar 7. Grafik Perubahan Tingkat Kekeringan di Provinsi Jawa Timur Tahun 2013-2015

Grafik di atas menunjukkan bahwa tingkat kekeringan ratarata di Provinsi Jawa Timur pada tahun 2013 hingga 2015 sangat tinggi yaitu berada pada rentang nilai 0,9 hingga 1 . Dimana nilai ini berdasarkan klasifikasi kelas kekeringan TVDI yang dikemukakan oleh Sandholt (2002) termasuk dalam tingkat kekeringan yang kering. KESIMPULAN DAN SARAN

Adapun beberapa hal yang dapat disimpulkan dari penelitian ini adalah:

1) Nilai indeks kekeringan rata-rata pada tahun 2013 sebesar 0,993, tahun 2014 sebesar 0,986, dan pada tahun 2015 sebesar 1.

2) Hasil perhitungan menunjukkan bahwa tingkat kekeringan rata-rata di Provinsi Jawa Timur pada tahun 2013 hingga 2015 sangat tinggi yaitu berada pada rentang nilai 0,9 hingga 1. Dimana nilai ini berdasarkan klasifikasi kelas kekeringan TVDI yang dikemukakan oleh [7] termasuk dalam tingkat kekeringan yang kering.

Berdasarkan penelitian ini, data satelit Landsat-8 secara umum dapat digunakan untuk memantau kekeringan secara multitemporal. Pengecekan kembali data yang telah diolah sangat diperlukan terutama dalam perhitungan parameter yang digunakan dalam perhitungan nilai indeks kekeringan TVDI.

\section{DAFTAR PUSTAKA}

[1] Ibrahimi, A. A. (2013). Aplikasi Penginderaan Jauh untuk Memetakan Kekeringan Lahan dengan Metode Temperature Vegetation Dryness Index (TVDI) (Studi Kasus : TN Bromo Tengger Semeru). Surabaya: Jurusan Teknik Geomatika, Fakultas Teknik Sipil dan Perencanaan, Institut Teknologi Sepuluh Nopember.

[2] Badan Meteorologi, Klimatologi dan Geofisika. (2015). Informasi Index El Nino. Dipetik Desember 18, 2015, dari Badan Meteorologi, Klimatologi, dan Geofisika (BMKG): http://www.bmkg.go.id/

[3] Adiningsih, E. S. (2014). Tinjauan Metode Deteksi Parameter Kekeringan Berbasis Data Penginderaan Jauh. Jakarta: Pusat Teknologi dan Data Penginderaan Jauh, Lembaga Penerbangan dan Antariksa Naional.

[4] Pemerintah Provinsi Jawa Timur. (2015, July 9). Sekilas Jawa Timur. Dipetik Januari 4, 2016, dari Media Jatim Menuju E-Government: http://jatimprov.go.id/

[5] Badan Pertanahan Nasional Provinsi Jawa Timur. Peta Jawa Timur. Diambil kembali dari BPN Provinsi Jawa Timur: https://bpnjatim.wordpress.com/peta-jawatimur/ 
[6] Northrop, A. (2015). IDEAS - LANDSAT Products Description Document. United Kingdom: Telespazio VEGA UK Ltd.

[7] Sandholt, I. A. (2002). Perspectives in Using a Remotely Sensed Dryness Index in Distributed Hydrological Models at the River-basin Scale. Hydrological Process. 